\title{
TOWARDS THE NEW CROATIAN TERRESTRIAL REFERENCE FRAME BASED ON CROPOS - PRELIMINARY RESULTS
}

\author{
Marko Pavasović, Marijan Marjanović, Tomislav Bašić
}

Preliminary note

Since the establishment of CROPOS, almost seven years have passed. Initial and also the last adjustment CROPOS network was carried out in 2008 using only seven 24h session data in GPS Week 1503 (ETRF2000 R05; e2008,83). In the recent period there have been significant changes - Croatian State Geodetic Administration (CSGA) signed an agreement on the exchange of data of national positioning systems neighboring countries: Slovenia (SIGNAL), Hungary (GNSSnet.hu), Montenegro (MontePOS), Federation of Bosnia and Herzegovina (FBiHPOS) and Republika Srpska (SRPOS). This paper presents the results of long-term stability of coordinates of CROPOS stations through absolute comparison of ETRF2000 coordinates from initial adjustment with the combined networked solution of CROPOS and nearby positioning systems, calculated on the basis of 1463 daily solutions for the time span of four years.

Keywords: absolute comparison, combined network solution, CROPOS, daily solution, ETRF2000.

U susret novom Hrvatskom terestričkom referentnom okviru temeljenom na CROPOS-u - preliminarni rezultati

Prethodno priopćenje

Od uspostave CROPOS-a do danas prošlo je gotovo 7 godina. Inicijalno, a u jedno i posljednje izjednačenje CROPOS mreže je provedeno u 2008. godini na temelju sedam 24 satnih sesija podataka u GPS tjednu 1503 (ETRF2000 R05, e2008,83). U posljednje vrijeme došlo je do značajnih promjena Državna geodetska uprava (DGU) potpisala je sporazum o razmjeni podataka nacionalnih pozicijskih sustava susjednih zemalja: Slovenije (SIGNAL), Mađarske (GNSSnet.hu), Crne Gore (MontePOS), Federacije Bosne i Hercegovine (FBiHPOS) i Republike Srpske (SRPOS). U radu su prikazani rezultati dugoperiodične stabilnosti koordinata CROPOS stanica kroz apsolutnu usporedbu ETRF2000 koordinata iz inicijalnog izjednačenja CROPOS mreže s koordinatama dobivenih kombiniranim umreženim rješenjem CROPOS-a i susjednih pozicijskih sustava, izračunatog na temelju 1463 dnevna rješenja za razdoblje od četiri godine.

Ključne riječi: apsolutna usporedba, CROPOS, dnevno rješenje, ETRF2000, kombinirano umreženo rješenje.

\section{Introduction}

Nowadays, national positioning systems (POS), based on GPS/GNSS permanent stations are unavoidable part of everyday geodetic practice, providing 365/24/7 reliable services to its users. In 2008 Croatian State Geodetic Administration (CSGA) established CROatian POSitioning System (CROPOS) - network of 30 GNSS permanent stations approximately $70 \mathrm{~km}$ distanced apart over the territory of Republic of Croatia. CROPOS is the first positioning system in region with fully implemented 3D coordinate transformation model called T7D (Transformation 7-parameter Distortion) [1] thus providing modern approach to everyday geodetic tasks.

Possibilities of POSs are numerous, both in professional and in scientific field. The quality of POS is measurable by quality of providing services to its users. Precondition to this is primarily long-term stability of POS that is coordinates of its permanent GPS/GNSS stations.

\section{An overview of CROPOS development}

According to [5], Coordinate Reference System (CRS) is a coordinate system related to the real world by (geodetic) datum. Datum defines the position of the origin, scale and orientation of coordinate axes, including the definition of mathematical approximation of the Earth - ellipsoid.

Republic of Croatia has historically inherited the horizontal (2D) coordinate reference system as a former member of Austrian-Hungarian Monarchy (in 1901) colloquially called HDKS (hrv. Hrvatski državni koordinatni sustav), Hermannskögel or HR1901. HDKS was realized by astro-geodetic measurements of Military Geodetic Institute (MGI) in $1^{\text {st }}$ order triangulation network. It was inhomogenously adjusted in 7 separate blocks by conditional measurements [6]. Fundamental point (origin) of HDKS was situated at Hermannskögel hill, near Vienna. For the mathematical approximation of Earth's shape, the Bessel 1841 rotation ellipsoid was selected.

Following modern European trends, as well as development of satellite positioning systems (primarily GPS and GLONASS), poor documentation of inherited horizontal reference system and its inhomogeneity $(1 \div 2 \mathrm{~m}$ at state level, few $\mathrm{dm}$ at county level and $\sim 10 \mathrm{~cm}$ at city levels), were more than a good reason to introduce changes, that is to redefine a national horizontal (as well as height and gravimetric) system [4]. On the proposal of the Working Group from University of Zagreb - Faculty of Geodesy (formed on request by CSGA), on $4^{\text {th }}$ August, 2008 the Government of Republic of Croatia brought the "Decree on establishing new official geodetic datums and map projections of Republic of Croatia" (hrv. Odluka o utvrđivanju novih službenih geodetskih datuma $i$ ravninskih kartografskih projekcija Republike Hrvatske) [16]. According to the Decree, Republic of Croatia has adopted a new horizontal reference system called "Croatian Terrestrial Reference System 1996" - CTRS96 (hrv. Hrvatski terestrički referentni sustav 1996 HTRS96), based on European Terrestrial Reference System 1989 (ETRS89) with Geodetic Reference System 1980 (GRS80) level-ellipsoid as a mathematical and physical approximation of Earth's shape [6]. 
In October 2007 the Ministry of Finance (MFIN) of Republic of Croatia, representatives of European Union Delegacy in Zagreb and company Trimble Europe signed the contract on realization of Croatian national positioning system with funds ensured from PHARE$2005(75 \%)$ and Croatian state budget (25\%) [12].

On $9^{\text {th }}$ December 2008, CSGA introduced Croatian Positioning System - CROPOS to official public use. CROPOS represents a network of 30 GNSS (Global Navigation Satellite System; including: USA NAVSTAR GPS, European Galileo and Russian GLONASS) continuously operating reference stations (CORS) evenly distributed over the territory of Croatia, approximately 70 km apart. Each CROPOS CORS is equipped with Trimble Net R5 GNSS receiver and Zephyr GNSS Geodetic II antenna (TRM55971.00 TZGD with elevation mask set to $5^{\circ}$ ). System is operative $365 / 24 / 7$ providing real time positioning to its users through differential positioning service (DPS) and high-precise positioning service (hrv. visokoprecizni pozicijski servis - VPPS) with 0,3-0,5 m (for DPS), 0,02 $\mathrm{m}$ horizontal and 0,04 m vertical (for VPPS) declared accuracy. CROPOS also provides postprocessing through geodetic precise positioning service (GPPS) by downloading CROPOS CORS data or generating virtual reference station (VRS) data in receiver independent exchange (RINEX) format via CROPOS RINEX web-shop with possible below $\mathrm{cm}$ level of accuracy.

CROPOS reference frame is defined due to European Terrestrial Reference Frame 2000 (ETRF2000; R05), transformed from ITRF2005 [8] using an adopted 14parameter transformation procedure according to EUREF TWG Memo specifications [15]. Initial adjustment of CROPOS network was done using $24 \mathrm{~h}$ session data for GPS Week 1503 (epoch 2008,83) [2; 12].

In June 2009 at $1^{\text {st }}$ CROPOS Conference held in Zagreb, CSGA, Surveying and Mapping Authority of the
Republic of Slovenia, Hungarian Institute of Geodesy, Cartography and Remote Sensing (FÖMI) and Real Estate Administration of Government of Montenegro signed an agreement on data exchange of border permanent stations of corresponding positioning systems: CROPOS, SIGNAL, GNSSnet.hu and MontePOS. With this agreement, CROPOS was supplemented with 13 reference stations (7 SIGNAL: KOPE, ILIB, TREB, CRNO, BREZ, PTUJ and VEPO; 4 GNSSnet.hu: NIZS, BARC, SIKL and BALE; 2 MontePOS: NIKS and TIVA) and represents total networked solution of 43 reference stations (Fig. 1).

In December 2013, CSGA, Federal Geodetic Administration of Bosnia and Herzegovina (FGA) and Republic Administration for Geodetic and Property Affairs of Republic of Srpska signed an agreement on data exchange of border permanent stations of corresponding positioning systems: CROPOS, FBiHPOS and SRPOS. With this agreement, CROPOS was supplemented with additional 5 reference stations (3 FBiHPOS: SANM, BOSG and MOST; 2 SRPOS: NOVI and BIJE) (Fig. 1). On $13^{\text {th }}$ November 2011 (GPSW 1662, DOY 317) CSGA disconnected IGS station Dubrovnik (DUBI) and established a new one (DUB2), located just $22 \mathrm{~m}$ away (Fig. 1). On 29 ${ }^{\text {th }}$ October 2012 (GPSW 1712, DOY 303) GSGA also established new permanent station at island Hvar (HVA2), inside Astronomical Observatory (Fig. 1). Both stations, DUB2 and HVA2 were included in CROPOS networked solution during 2015. Former IGS station Osijek (OSJE) was moved to Nova Gradiška (NGRD) and began operating on $14^{\text {th }}$ July 2013 (GPSW 1749, DOY 195). Station NGRD (Fig. 1) was also included in CROPOS networked solutions during 2015. CSGA also plans to establish data exchange with selected permanent stations of positioning system of Republic of Serbia - AGROS (hrv. aktivna geodetska referentna osnova Srbije).

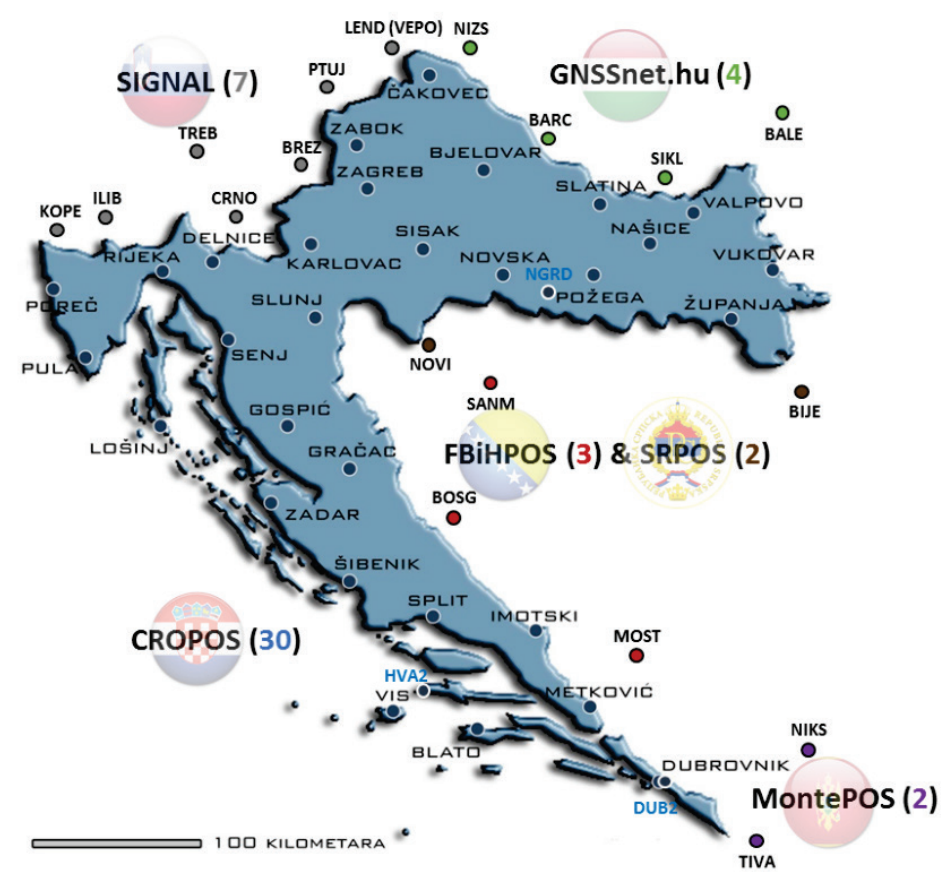

Figure 1 CROPOS networked solution (including SIGNAL, GNSSnet.hu, MontePOS, FBiHPOS and SRPOS) 
During 2011, CSGA proposed to EUREF EPN Centre to include 5 CROPOS stations (CAKO, DUB2, PORE, POZE and ZADA) in EUREF EPN. After the period of data analysis as well as fulfilling criteria according to [14], those stations were included in EUREF EPN as class $B$ stations on $16^{\text {th }}$ June $2013[10]$.

\section{Long-term stability of CROPOS reference frame}

As mentioned above, initial and also the last adjustment of CROPOS made, used only $24 \mathrm{~h}$ session data in GPSW 1503 (e2008,83) [2]. According to [9], a longterm solution of reference frame, defined using only GPS/GNSS measurements, can be given if there's a minimal period of 2,5 years of continuous measurements.

Processed data period of CROPOS and stations of nearby positioning systems in this work, was from $16^{\text {th }}$ November 2008 (GPSW 1506) to $31^{\text {st }}$ December 2012 (GPSW 1721), which is approximately 4 years of continuous data. CORS data processing as well as the adjusted (combined) networked solution (of CROPOS and nearby positioning systems) was done using AIUB Bernese GPS Software (version 5.0) [3]. Total amount of 54 reference stations (in 15 seconds registration interval) were included in data processing and adjustment procedure:

- 44 POS CORS (Fig. 1):

$\checkmark \quad 31$ CROPOS stations (including station HVA2),

$\checkmark 7$ SIGNAL stations,

$\checkmark \quad 4$ GNSSnet.hu stations and

$\checkmark 2$ MontePOS stations.

- $10 \mathrm{IGS} / \mathrm{EPN}$ reference stations:

$\checkmark 3$ Croatian IGS/EPN stations (DUBI, DUB2 and OSJE),

$\checkmark \quad 2$ IGS control stations (GOPE and POTS) and

$\checkmark \quad 5$ IGS (adjustment fixed) stations (GRAZ, MATE, ZIMM, WTZR and PENC).

In Tab. 1 numerical indicators of input and output data are shown.

Table 1 Numerical indicators of input and output data

\begin{tabular}{|c|c|}
\hline Total number of daily solutions: & 1463 \\
\hline Number of RINEX data files $(15 \mathrm{~s})$ : & 69894 \\
\hline Total number of measurements $(30 \mathrm{~s}$; L1, L2, C/A, P): & 3633733829 \\
\hline Number of cycle slips $\left(1^{\text {st }}\right.$ pass $)$ : & 1570933 \\
\hline Number of marked measurements $\left(1^{\text {st }}\right.$ pass $)$ : & 20979500 \\
\hline GPSEST float solution ( $1^{\text {st }}$ solution) - total number of unknowns: & 5054687 \\
\hline \multicolumn{2}{|l|}{$\begin{array}{ll}\text { Ambiguity calculation } \\
\end{array}$} \\
\hline Input (L1 + L2): & 9007558 \\
\hline Left (L1 + L2): & 2892870 \\
\hline Solved: & $68 \%$ \\
\hline \multicolumn{2}{|l|}{ GPSEST fixed solution } \\
\hline Total number of unknowns: & 2769124 \\
\hline Coordinate unknowns: & 203934 \\
\hline Ambiguity unknowns: & 1409564 \\
\hline Troposphere unknowns: & 384812 \\
\hline Number of measurements (L3): & 547408235 \\
\hline
\end{tabular}

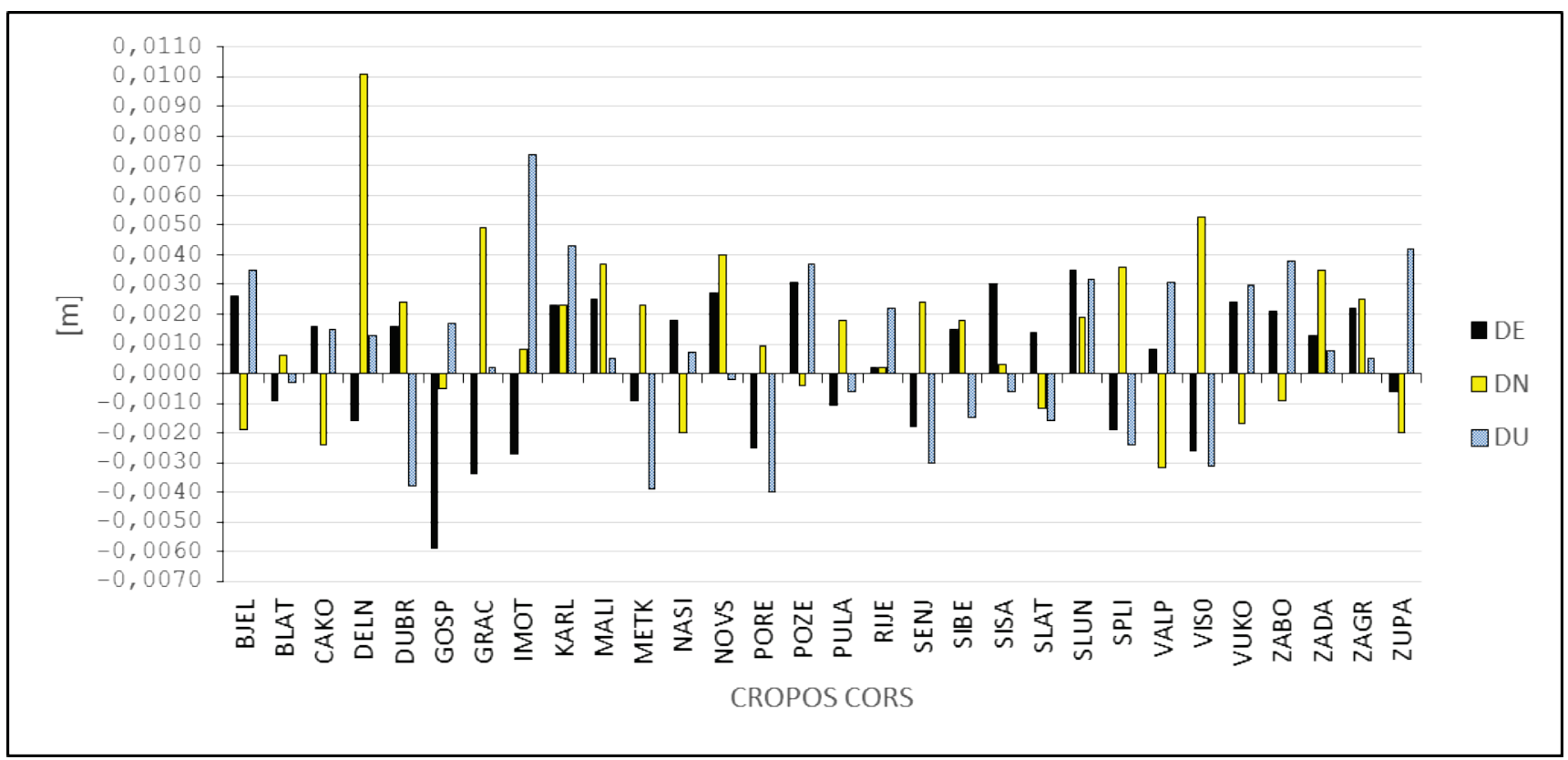

Figure 2 Absolute comparison of CROPOS CORS coordinates - ETRF2000 (R05) e2008,83 vs ETRF2000 (ITRF2008) e2010,94 ( $\Delta E, \Delta N, \Delta U)$

Regarding large amounts of numerical indicators shown in Tab. 1, special attention was paid to input data sorting as well as frequent control of output data in order to avoid any coarse error in data processing and 
adjustment procedure. Adjustment is made by fixing 5 IGS stations (GRAZ, MATE, ZIMM, WTZR and PENC) using ITRF2008 [7] station coordinates, velocities as well as IGS final precise orbits in mean epoch of all 1463 daily solutions - 2010,94. Ambiguity calculation was obtained using QIF (Quasi Ionosphere Free) strategy [3]. For the $a$ priori troposphere modeling, that is ZPD (Zenith Path Delay) model and mapping function, Dry Neill and Wet Neill models were used [3]. Initial adjustment of CROPOS network included only original 30 CORS, without stations of nearby positioning systems. This combined networked solution includes above mentioned 44 POS CORS. In order to compare coordinates of 30 CROPOS CORS from initial adjustment (ETRF2000 R05; e2008,83) with ones from this combined networked solution, coordinates of original 30 CROPOS CORS were extracted and transformed to ETRF2000 according to [15].

The absolute comparison of original 30 CROPOS CORS coordinates is shown in Fig. 2. Corresponding statistics are presented in Tab 2. ETRF2000 absolute coordinate differences $(\Delta E, \Delta N, \Delta U)$ shown in Fig. 2, indicate larger values for CROPOS stations DELN $(\Delta N=$ $10,1 \mathrm{~mm})$, IMOT $(\Delta U=7,4 \mathrm{~mm})$ and GOSP $(\Delta E=-5,9$ $\mathrm{mm})$ are probably caused by prominent multipath effect at these stations as shown in previous researches [13; 11]. Mean standard deviation value of $\sim 2,5 \mathrm{~mm}$ for all components $(E, N, U)$ indicates the existence of long-term stability of CROPOS coordinates for the time span of 4 years.

Table 2 Statistics of absolute comparison of 30 CROPOS CORS coordinates

\begin{tabular}{|c|c|c|c|c|c|c|}
\multicolumn{6}{|c|}{ ETRF2000 (R05) e2008,83 (7 daily solutions) vs ETRF2000 (ITRF2008) e2010,94 (1463 daily solutions) } \\
\hline Statistics & $\Delta X / \mathrm{m}$ & $\Delta Y / \mathrm{m}$ & $\Delta Z / \mathrm{m}$ & $\Delta E / \mathrm{m}$ & $\Delta N / \mathrm{m}$ & $\Delta U / \mathrm{m}$ \\
\hline Min. & $-0,0057$ & $-0,0053$ & $-0,0022$ & $-0,0059$ & $-0,0032$ & $-0,0040$ \\
\hline Max. & 0,0054 & 0,0038 & 0,0080 & 0,0035 & 0,0101 & 0,0074 \\
\hline Avg. & $-0,0005$ & 0,0002 & 0,0014 & 0,0004 & 0,0013 & 0,0007 \\
\hline St.dev. & 0,0030 & 0,0027 & 0,0023 & 0,0024 & 0,0028 & 0,0028 \\
\hline
\end{tabular}

\section{Conclusion}

The analysis of coordinate stability of CROPOS stations through the period of 4 years was obtained by comparing the results of the initial adjustment of CROPOS network, based on combination of 7 daily solutions in GPSW 1503 with combination of 1463 daily solutions for the period from $16^{\text {th }}$ November 2008 (GPSW 1506) to $31^{\text {st }}$ December 2012 (GPS week 1721). This comparison indicates to a high degree of stability and reliability of CROPOS reference frame. Preliminary results of the analysis in this work, draw the question whether we can consider CROPOS the "new" Croatian terrestrial reference frame. The answer to this question will be given through results of ongoing scientific research including longer operating time span of CROPOS and nearby positioning systems.

The potential that CROPOS offers is invaluable and therefore will certainly be a topic of future professional and scientific researches.

\section{Acknowledgements}

Authors would like to thank Croatian State Geodetic Administration (CSGA) for seconded CROPOS data for the purposes of this scientific research.

\section{References}

[1] Bašić, T. New geoid model of Republic of Croatia and improvement of T7D transformation model. Study for Croatian State Geodetic Administration. University of Zagreb - Faculty of Geodesy. Zagreb, 2009. pp. 1-68. (in Croatian)

[2] Marjanović, M. Application of GPS measurements for determining horizontal and vertical movements of the Adriatic microplate. Doctoral Dissertation. University of
Zagreb - Faculty of Geodesy. Zagreb, 2008. pp. 1-293. (in Croatian)

[3] Dach, R.; Beutler, G., Bock, H.; Fridez, P.; Gäde, A.; Hugentobler, U.; Jäggi, A.; Meindl, M.; Mervart, L.; Prange, L.; Schaer, S.; Springer, T.; Urschl, C.; Walser, P. Bernese GPS Software Version 5.0. User manual. Astronomical Institute University of Bern (AIUB), Bern, Switzerland, January 2007. pp. 1-612.

[4] Bašić, T.; Feil, L.; Lapaine, M. Scientific-technical explanation of the Decree on establishing official geodetic reference coordinate system of the Republic of Croatia. Croatian State Geodetic Administration \& University of Zagreb - Faculty of Geodesy. Zagreb, June, 2004. pp. 1-16. (in Croatian)

[5] International Organization for Standardization (ISO). ISO19111: Geographic Information - Spatial Referencing by Coordinates. ISO Copyright Office. Geneva, 2003. pp. $1-43$.

[6] Bašić, T.; Markovinović, D.; Rezo, M.; Hećimović, Ž.; Šljivarić, M.; Špoljarić, D. Proposal of new official geodetic datums of Republic of Croatia. Study for Croatian State Geodetic Administration. University of Zagreb Faculty of Geodesy. Zagreb, 2000. pp. 1-93. (in Croatian)

[7] Altamimi, Z.; Collilieux, X.; Boucher, C. ITRF2008 an improved solution of the international terrestrial reference frame. // Journal of Geodesy. 85, 8(2011), pp. 457-473. DOI: 10.1007/s00190-011-0444-4

[8] Altamimi, Z.; Collilieux, X.; Legrand, J.; Garayt, B.; Boucher, C. ITRF2005 - A new release of the International Terrestrial Reference Frame based on time series of station positions and Earth Orientation. // Journal of Geophysical Research: Solid Earth, American Geophysical Union. 112, B9(2007), pp. 1-19. DOI: 10.1029/2007JB004949

[9] Blewitt, G.; Lavallée, D. Effect of annual signals on geodetic velocity. // Journal of Geophysical Research. 107, B7(2002), pp. 1-11. DOI: 10.1029/2001JB000570

[10] Marjanović, M. CROPOS - status and system development. // Conference proceedings of $3^{\text {rd }}$ CROPOS conference, Opatija, 24 - 25 October 2013. Marjanović, M., Bašić, T. (ed.). Zagreb: Croatian State Geodetic Administration, University of Zagreb - Faculty of Geodesy, Croatian 
Chamber of Chartered Geodetic Engineers. pp. 16-20. (in Croatian)

[11] Pavasović, M.; Bačić, Ž.; Rezo, M.; Bjelotomić, O.; Markovinović, D.; Bašić, T.: Analysis of time-independent signals in CROPOS network. // Conference proceedings of the $2^{\text {nd }}$ CROPOS conference, University of Zagreb Faculty of Geodesy, Zagreb, 2011. Bašić, Tomislav (ed.). Zagreb: Croatian State Geodetic Administration, University of Zagreb - Faculty of Geodesy, Croatian Chamber of Chartered Geodetic Engineers, Croatian Geodetic Society. pp. 25-135. (in Croatian)

[12] Marjanović, M.; Miletić, I.; Vičić, V. CROPOS - first six months of the operational system. // Conference proceedings of the $1^{\text {st }}$ CROPOS conference, Zagreb, 8 - 9 June 2009. Marjanović, Marijan (ed.). Zagreb: Croatian State Geodetic Administration, Croatian Geodetic Society. pp. 15-21. (in Croatian)

[13] Rezo, M.; Bačić, Ž. CROPOS - quality of the system. // Conference proceedings of the symposium "Geodesy and geoinformatics in the design, construction and administration of the state and municipal infrastructure", Opatija 23 - 25 October 2009. Markovinović, Danko (ed.). Zagreb: Croatian Chamber of Chartered Geodetic Engineers, 2009, pp. 162-170. (in Croatian)

[14] Bruyninx, C.; Altamimi, Z.; Caporali, A.; Kenyeres, A.; Lidberg, M.; Stangl, G.; Torres, J. A. Guidelines for EUREF Densifications. IAG sub-commission for the European Reference Frame - EUREF. Version 5 (28.05.2013.).URL:ftp://epncb.oma.be/pub/general/Guideli nes_for_EUREF_Densifications.pdf (13.11.2014).

[15] Altamimi, Z.; Boucher, C. Memo: Specifications for reference frame fixing in the analysis of a EUREF GPS campaign. Version 8 (18.05.2011.). EUREF TWG. URL: etrs89.ensg.ign.fr/memo-V8.ps (14.11.2014).

[16] Official gazette "Narodne novine" no. 110/2004. Decree on establishing new official geodetic datums and map projections of Republic of Croatia. URL: http://narodnenovine.nn.hr/clanci/sluzbeni/2004_08_110_2107.html (13.11.2014). (in Croatian)

\section{Authors' addresses}

Marko Pavasović, PhD

University of Zagreb - Faculty of Geodesy

Fra Andrije Kačića Miošića 26, 10000 Zagreb, Croatia

E-mail: marko.pavasovic@geof.hr

Marijan Marjanović, PhD

Croatian State Geodetic Administration - Central Office

Gruška 20, 10000 Zagreb, Croatia

E-mail: marijan.marjanovic@dgu.hr

Tomislav Bašić, Full Professor PhD

University of Zagreb - Faculty of Geodesy

Fra Andrije Kačića Miošića 26, 10000 Zagreb, Croatia

E-mail: tomislav.basic@geof.hr 